\title{
The Role of the Kidd-Antibodies in Posttransfusion Reactions
}

\author{
Ljubinka I. Nikolić1 ${ }^{1}$ Emina S. Čolak², Saša A. Kadija ${ }^{1}$, \\ Tatjana Ž. Ilić-Mostićs ${ }^{3}$, Nenad N. Mladenović ${ }^{4}$, Srđan Z. Markovićs,6, \\ Dragana A. Kastratović 6 , Tanja Lj. Stričević ${ }^{7}$, Gradimir D. Bogdanović ${ }^{4}$ \\ ${ }^{1}$ Clinic for Gynecology and Obstetrics, Clinical Center of Serbia, Belgrade, Serbia \\ ${ }^{2}$ Institute of Medical Biochemistry, Clinical Center of Serbia, Belgrade, Serbia \\ ${ }^{3}$ Center for Anesthesiology and Reanimatology, Clinical Center of Serbia, Belgrade, Serbia \\ ${ }^{4}$ Blood Transfusion Institute of Serbia, Belgrade, Serbia \\ ${ }^{5}$ Faculty of Physical Chemistry, University of Belgrade, Belgrade, Serbia \\ ${ }^{6}$ Clinical Centre of Serbia, Belgrade, Serbia \\ 7 Hospital for Cerebrovascular Diseases "St Sava”, Belgrade, Serbia
}

\section{SUMMARY}

Topic: The Kidd blood group (Jk) was discovered in 1951 and according to International Society for blood transfusion (ISBT) the Kidd (Jk) blood group is registered under the number 009. Antigens of the Kidd system are detected only on RBCs and kidney. Incompatibile transfusion in $\mathrm{Jk}$ blood group can provoke sensitization and appearance of anti-Jka or anti-Jkb antibodies. Jk antibodies are common cause of delayed hemolytic transfusion reactions (DHTRs). Although Kidd antibodies can lead to acute reactions, kidney damage and hemoglobinuria are very rare. More important is Kidd-antibody ability for delayed hemolytic reactions. The aim is to underline Jka antibodies laboratory characteristics, their role in delayed posttransfusion reactions and possible complications of blood transfusions. The topic position in scientific/professional public: Kidd-antibodies, usually, destroy transfused red cells after a variable period of between 7 and 21 days. DHTR is the result of anti-Jka antibodies tendency to fall rapidly to undetectable levels even after incompatible transfusion. Anti-Jka has been reported as reason for kidney transplant rejection. There were examples of anti-Jka that react only when preservatives such as $p$-hydroxybenzoic acid (parabens), Na-azide or related compounds, antibiotics are present in the reaction mixture. Also, patient's therapy with antibiotics and monoclonal antibodies could cause false positive RBC antibody.

Further action needed for better topic covering in future: Except in life threatening condition, reduction of allogenic blood transfusion is recommended. Increase the number of autologous transfusions in all cases when the patient's clinical condition allows. Antigen-free RBC ie universal RBC would be the best choice for transfusion. It is essential to perform extended erythrocyte phenotyping prior to initiation of monoclonal antibodies therapy. As a minimum blood typing for Rh, K, Jka, Jkb, Fya, Fyb and Ss antigens should be done for every patient who is planned to be treated with monoclonal antibodies. Overcoming this problem is very important for patients who are transfusion-dependent or candidates for monoclonal antibody therapy, or candidates for kidney transplantation.

Keywords: transfusion, Kidd system, Jka antibodies, parabens, transplantation, antibiotics 


\section{TOPIC}

The Kidd blood group (Jk) was discovered in 1951 and according to International Society for blood transfusion (ISBT) the Kidd (Jk) blood group is registered under the number 009. It was named after a patient, a pregnant woman Mrs. Kidd [1]. Antigens of the Kidd system are detected only on RBCs and kidney [2,3]. They are carried by an integral membrane glycoprotein, which transports urea through the RBC's membrane [4]. Jka antigen is known as urea transporter UT-B (synonyms: UT3, UT11) [5]. Kidd antigen and UT-B are coded by gene chromosome 18q11-q12 [6]. The null phenotype $\mathrm{Jk}(\mathrm{a}-\mathrm{b}-)$ is usually results from homozygosity for a silent gene at the Jk locus and it is rare in most populations. Incompatibile transfusion in Jk blood group can provoke sensitization and appearance of anti-Jka or Jkb antibodies [7-9]. Jk antibodies are common cause of delayed hemolytic transfusion reactions (DHTRs) [8]. Alloimmunization is more common in females $(2.38 \%)$ than males (1.68\%). One in 1200 transfused patients experience a delayed haemolytic transfusion reaction $[10,11]$.

It is quite intriguing for clinical practice that in approximately $50 \%$ of patients with detected Jka antibodies neither clinical nor laboratory signs of transfusion hemolytic reaction were not found $[10,11]$. Clinical and laboratory signs of a haemolysis reaction will not be demonstrated in 2 cases: 1 ) if the present Ig antibodies belong to the IgG2 or IgG4 class, which do not bind complement, and 2) in cases of detecting positivity to Jka, in fact, it is a reaction caused by preservatives present in using reagents. The aim is to underline Jka antibodies laboratory characteristics, their role in delayed posttransfusion reactions and possible complications of blood transfusions.

\section{THE TOPIC POSITION IN SCIENTIFIC/PROFESSIONAL PUBLIC}

Anti-Jka and anti-Jkb are uncommon. They are usually warm-reacting IgG1 and IgG3 but may also include IgG2, IgG4 or IgM. Approximately $50 \%$ of anti-Jka and anti-Jkb antibodies are capable of binding complement [12]. Kidd antibodies have a tendency to fall rapidly to low or undetectable levels in the plasma, therefore they are often difficult to detect in pretransfu- sion testing. The Kidd antibodies react better on antiglobulin testing with polyspecific anti$\operatorname{IgG}+$ anti-C3d as well as with monospecific anti-C3d since they are usually detected indirectly through the complement as they bind to RBCs. These antibodies usually give stronger hemagglutination with enzyme treated test red cells [13]. Anti-Jka antibodies show antigen dosage effect, so the most anti-Jka react more intensely with $\mathrm{Jk}(\mathrm{a}+\mathrm{b}-)$ red cells than $\mathrm{Jk}(\mathrm{a}+\mathrm{b}+)$ red cells. Kidd system antibodies are noted, in developing an anamnestic response to the antigen $[8,14]$.

Anti-Jka antibodies may cause acute and delayed hemolytic transfusion reactions (DHTR). Although Kidd antibodies can lead to acute reactions, kidney damage and hemoglobinuria are very rare [15]. More important is Kidd-antibody ability for delayed hemolytic reactions. Kidd-antibodies, usually, destroy transfused red cells after a variable period of between 7 and 21 days $[8,16]$.

DHTRs commonly result in posttransfusion jaundice and may significantly reduce the patient's hemoglobin level [8]. Patients may be free of any hemolytic reactions when bilirubin and lactate dehydrogenase are in the normal range, so then we are talking about laboratory DHTR. DHTR is the result of Jka antibodies tendency to fall rapidly to undetectable levels even after incompatible transfusion. It is known from literature that one-third of DHTR is caused by anti-Jka antibodies $[8,10,17,18]$. For this reason, it is essential to perform crossmatch before each transfusion, because this is the only way to discover anamnestic (memory) RBC antibodies $[8,14]$. Anti-Jka has been reported as reason for kidney transplant rejection [19]. In patient noncompliant with immunosuppressive regimes, acute graft rejection occurred simultaneously with the occurrence of a Kidd antibodies [20,21]. Overcoming this problem is very important for patients who are transfusion-dependent or candidates for monoclonal antibody therapy, or candidates for kidney transplantation $[22,23]$.

Preservatives Na-azide and esters of parabens, and antibiotics are added to commercially available LISS(C-LISS) ${ }^{\circledR}$ to prevent microbial growth [24-26]. The additives used for the storage, preservation, and coloring of blood bank reagents can be a source of false 
positive agglutination reactions [27]. Agglutination of red blood cells used for blood typing, antibody detection and identification may be related to the presence of these materials in blood bank reagents. These substances include acriflavin and other dyes; antibiotics, such as penicillin and neomycin; EDTA; caprylate; and occasionally saline $[27,28]$. There were examples of anti-Jka that react only when preservatives such as p-hydroxybenzoic acid (parabens) or related compounds are present in the reaction mixture [29-31]. Antibodies against preservatives like $\mathrm{Na}$-azide were also reported $[30,32]$. When results are inexplicitly positive by using commercially reagents, the solution could be to repeat immunohematological tests using saline instead of LISS, and additionally wash commercially RBCs [24,33].

Antibiotics used for classic patient therapy and antibiotics added to blood groups reagents for immunohematological transfusion testing could be false positive to RBC antibodies [34] The most frequent antibiotics used as a preservative in diluents for commercial RBCs reagents, such as chloramphenicol, neomycin sulfate, co-trimoxazole, and gentamycin could cause false positive RBC antibodies $(\mathrm{Ab})[26,35]$. In these cases of false positive $\mathrm{RBC} A \mathrm{~b}$ there were no clinical or laboratory evidence of hemolysis $[5,18,26,34,36]$.

Antigen-free RBC ie universal RBC would be the best choice for transfusion, and using specific monoclonal antibodies would be the therapeutic choice in patients who are sensitive to erythrocyte antigens $[37,38]$. It is recommended, prior to initiate monoclonal antibody therapy, along with baseline $\mathrm{ABO}$, $\mathrm{RhD}$, DAT and IAT, to perform extended RBC phenotype: Rh, MNSs, Kell, Kidd and Duffy blood group systems. Extended RBC phenotyping is important in the provision of phenotype-matched RBC for future transfusions and thus reduces the possibility of RBC antibodies formation $[22,23]$. Phenotyping may be inaccurate if a patient has received a blood transfusion in the previous 3 months $[39,40]$. In this case, the genotype is unaffected, and blood group genotyping is the method of choice $[22,41,42]$.

Obviously, these can be confusing or may be a source of problems in the interpretation of results in various ways. Due to the low incidence of existing undiscovered Kidd antibodies, the authors suggest a multicentric academic observation studies, that would save the data in database which give the chance to upgrade the guidelines. Data exchange among world-renowned experts would make this problem more understandable and easier to fix [43-45].

\section{FURTHER ACTION NEEDED FOR BETTER TOPIC COVERING IN FUTURE}

Except in life threatening condition, reduction of allogenic blood transfusion is recommended. Increase the number of autologous transfusions in all cases when the patient's clinical condition allows.

Antigen-free RBC ie universal RBC would be the best choice for transfusion.

Using specific monoclonal antibodies against RBC antibodies would be the therapeutic choice in patients who are sensitized to erythrocyte antigens.

Transfusiologist has to perform crossmatch in order to make transfusion decision, because this is the only way to discover unexpected $\mathrm{RBC}$ antibodies.

It is essential to perform extended erythrocyte phenotyping prior to initiation of monoclonal antibodies therapy or renal transplantation. As a minimum blood typing for Rh, K, Jka,Jkb, Fya, Fyb and Ss antigens should be done for every patient who is planned to be treated with monoclonal antibodies.

In patients treated with monoclonal antibodies who were already transfused in the last 3 months period, the method of choice would be genetic blood group testing.

Multicentric academic observation studies would form database which will upgrade the blood transfusion guidelines in testing and improve transfusion safety.

\section{REFERENCES}

1. Race RR, Sanger R, Allen FH Jr, Diamond LK, Niedziela B. Inheritance of the human blood group antigen Jka. Nature. 1951;168(4266):207-8.

2. Olivès $B$, Martial $S$, Mattei MG, Matassi G, Rousselet G, Ripoche P, Cartron JP, Bailly P. Molecular characterization of a new urea transporter in the human kidney. FEBS Lett. 1996;386(2-3):156-60.

3. Daniels G, Kidd Blood Group System, Human Blood Groups,2013:325-335.

4. Pourazar A. Red cell antigens: Structure and function. Asian J Transfus Sci. 2007;1(1):24-32. 
5. Levin EJ, Zhou M. Structure of Urea Transporters. Subcell Biochem. 2014;73:65-78

6. Inoue H, Jackson SD, Vikulina T, Klein JD, Tomita $\mathrm{K}$, Bagnasco SM. Identification and characterization of a Kidd antigen/UT-B urea transporter expressed in human colon. Am J Physiol Cell Physiol. 2004;287(1):C30-C35.

7. Olives B, Mattei MG, Huet M, et al. Kidd blood group and urea transport function of human erythrocytes are carried by the same protein. J Biol Chem 1995;270:15607-10.

8. Siddon AJ, Kenney BC, Hendrickson JE, Tormey CA. Delayed haemolytic and serologic transfusion reactions: pathophysiology, treatment and prevention. Curr Opin Hematol. 2018;25(6):459-467.

9. Bird GWG. Some aspects of serological specificity. Transfusion. 1990;30(5):390-400.

10. Tormey CA, Stack G. Limiting the extent of a delayed hemolytic transfusion reaction with automated red blood cell exchange. Arch Pathol Lab Med. 2013;137(6):861-4.

11. Karafin MS, Tan S, Tormey CA, Spencer BR, Hauser RG, Norris PJ, Roubinian NH, Wu Y, Triulzi DJ, Kleinman S, Gottschall JL, Hendrickson JE. Prevalence and risk factors for RBC alloantibodies in blood donors in the Recipient Epidemiology and Donor Evaluation Study-III (REDS-III). Transfusion. 2019;59(1):217-225.

12. Hendrickson JE, Tormey CA. Understanding red blood cell alloimmunization triggers. Hematology Am Soc Hematol Educ Program. 2016;2016(1):446451.

13. Altaha YH, Jackson DE. Pre-transfusion serological testing: are we doing it right? Hematol Transfus Int J. 2015;1(2):53-55.

14. Hendrickson JE, Desmarets M, Deshpande SS, Chadwick TE, Hillyer CD, Roback JD, Zimring JC. Recipient inflammation affects the frequency and magnitude of immunization to transfused red blood cells. Transfusion. 2006;46(9):1526-36.

15. Giovannetti G, Pauselli S, Barrella G, Neri A, Antonetti L, Gentile G, Iacobini M, Girelli G, Coluzzi $S$. Severe warm autoimmune haemolytic anaemia due to anti-Jk(a) autoantibody associated with Parvovirus B19 infection in a child. Blood Transfus. 2013;11(4):634-5.

16. Hamilton JR, Kidd blood group system: outwardly simple with hidden complexity, ISBT Science Series. 2018;14(1):2C-05-03.

17. Pineda AA, Taswell. FH, Brzica SM Jr. Delayed Hemolytic Transfusion Reaction. Transfusion. 2003;18(1):1-7.

18. Tormey CA, Stack G. The persistence and evanescence of blood group alloantibodies in men. Transfusion 2009;49:505-12.
19. Holt S, Donaldson H, Hazlehurst G, Varghese Z, Contreras M, Kingdon E, Sweny P, Burns A. Acute Transplant Rejection Induced By Blood Transfusion Reaction to the Kidd Blood Group System. Nephrol Dial Transplant 2004; 19: 2403-6.

20. Hamilton JR. Kidd blood group system: a review. Immunohematology 2015;31:29-35

21. Rourk A, Squires JE. Implications of Kidd blood group system in renal transplantation. Immunohematology 2012;3:91-4.

22. Lancman G, Arinsburg S, Jhang J, Cho HJ, Jagannath S, Madduri D. et al. A. Blood Transfusion Management for Patients Treated With Anti-CD38 Monoclonal Antibodies. Frontiers in immunology, 2018;9, 2616. doi:10.3389/fimmu.2018.02616

23. Oostendorp M, Lammerts van Bueren JJ, Doshi P, Khan I, Ahmadi T, Parren PW, van Solinge WW, De Vooght KM. When blood transfusion medicine becomes complicated due to interference by monoclonal antibody therapy. Transfusion. 2015;55(6 Pt 2):1555-1562.

24. Halima D, Garratty G, Bueno R. An apparent anti-Jka reacting only in the presence of methyl esters of hydroxybenzoic acid, Transfusion 2003;22(6):521-4.

25. Gniadek TJ, Arndt PA, Leger RM, Zydowicz D, Cheng EY, Zantek ND. Drug-induced immune hemolytic anemia associated with anti-vancomycin complicated by a paraben antibody. Transfusion. 2018;58(1):181-188.

26. Sachan D, Kumar SA. Detection of antibodies to co-trimoxazole (preservative drug) interfering with routine red cell antibody screening. Asian J Transfus Sci. 2018;12(1):89-92.

27. Rajendran A, Deepthi Krishna G, Suresh B, Sreedhar Babu KV, Jothibai DS. Red cell incompatibility due to antibody against ingredient in column matrix: a rare entity. J Clin Sci Res 2016;5:40-48.

28. Howard PL. Blood Bank Reagents: Some Problems Related to Preservatives and Dyes. Transfusion. 1976;16(2):166-9.

29. Judd WJ, Steiner EA, Cochran RK. Paraben-associated autoanti-Jka antibodies. Three examples detected using commercially prepared low-ionic strength saline containing parabens. Transfusion. 1982;22(1):31-5.

30. Garratty G. In vitro reactions with red blood cells that are not due to blood group antibodies: a review. Immunohematology. 1998;14(1):1-11.

31. Judd WJ, Steiner EA, Oberman HA, Giacherio D. False-positive results with chemically modified anti-D do not indicate a need to use a separate, immunologically inert Rh control reagent. Transfusion. 1988;28(4):339-41.

32. Reviron $M$, Janvier $D$, Reviron J, Lagabrielle JF. An Anti I Cold Auto Agglutinin Enhanced 
in the Presence of Sodium Azide, Vox Sanguinis. 2009;46(4):211-216.

33. Fitzsimmons JM, Morel PA. The Effects of Red Blood Cell Suspending Media on Hemagglutination and the Antiglobulin Test. Transfusion 1979;19(1): 81-5.

34. Arndt PA, Leger RM, Garratty G. Serology of antibodies to second- and third-generation cephalosporins associated with immune hemolytic anemia and/or positive direct antiglobulin tests. Transfusion 1999;39:1239-46.

35. Pham BN, Gien D, Bensaad F, Babinet J, Dubeaux I, Rouger P, et al. Antibodies to co-trimoxazole (trimethoprim and/or sulfamethoxazole) related to the presence of the drug in a commercial low-ionicstrength solution. Transfusion. 2012;52:844-8.

36. Arndt PA, Garratty G, Wolf CF, Rivera M. Haemolytic anaemia and renal failure associated with antibodies to trimethoprim and sulfamethoxazole. Transfus Med. 2011;21:194-8.

37. Waterman $\mathrm{H}$, Howie $\mathrm{H}$, Wang $\mathrm{X}$, Zimring $\mathrm{JC}$. Use of monoclonal antibodies to RBC antigens as a therapeutic to allow incompatible transfusion. Blood 2015;126(23):1140.

38. Vemuri PK, Madala S, Bodiga VL, Veeravalli $\mathrm{S}$, Kurra NC. Efect of Arabica and canephora coffee bean extracts towards modification of red blood cell surface antigens. Int. Res. J. Pharm. 2018;9(5):91-5.

39. Chapuy $\mathrm{Cl}$, Nicholson RT, Aguad MD, Chapuy B, Laubach JP, Richardson PG, Doshi P, Kaufman $\mathrm{RM}$. Resolving the daratumumab interference with blood compatibility testing. Transfusion. 2015;55(6 Pt 2):1545-1554.

40. Deneys V, Thiry C, Frelik A, Debry C, Martin B, Doyen C. Daratumumab: Therapeutic asset, biological trap! Transfusion Clinique et Biologique, 2018;25(1):2-7.

41. Telen MJ. The Use of Genotyping in Transfusion Medicine. The Hematologist ASH news and reports. 2014;11(6):4-5.

42. Bub CB, Reis IND, Aravechia MG, Santos LD, Bastos EP, Kutner JM, Castilho L. Transfusion management for patients taking an anti-CD38 monoclonal antibody. Rev Bras Hematol Hemoter. 2018;40(1):25-29.

43. Marković SZ, Kastratović DA, Kubiak C, Demotes Mainard J. ECRIN - Needed in European Science. Hospital Pharmacology. 2015; 2(2):279-282 (www. hophonline.org)

44. Pirenne F, Bartolucci P, Habibi A. Management of delayed hemolytic transfusion reaction in sickle cell disease: Prevention, diagnosis, treatment. Transfus Clin Biol. 2017;24(3):227-231.

45. Australian and New Zealand Society of Blood Transfusion. Guidelines for Transfusion and Immu- nohaematology Laboratory Practice. Sydney: The Transfusion; 2016 [cited 2019 March 15]. https:// anzsbt.org.au/news/guidelines-for-transfusionand-immunohaematology-laboratory-practice-1stedition-2016/ 


\title{
Uloga Kidd-antitela u posttransfuzijskim reakcijama
}

\author{
Ljubinka I. Nikolić ${ }^{1}$ Emina S. Čolak ${ }^{2}$, Saša A. Kadija ${ }^{1}$, Tatjana Ž. Ilić-Mostić ${ }^{3}$, \\ Nenad N. Mladenović ${ }^{4}$, Srđan Z. Marković ${ }^{5,6}$, Dragana A. Kastratović 6 , \\ Tanja Lj. Stričević ${ }^{7}$, Gradimir D. Bogdanović ${ }^{4}$ \\ ${ }^{1}$ Klinika za ginekologiju i akušerstvo, Klinički centar Srbije, Beograd, Srbija \\ ${ }^{2}$ Centar za medicinsku biohemiju, Klinički centar Srbije, Beograd, Srbija \\ ${ }^{3}$ Centar za anesteziju i reanimaciju, Klinički centar Srbije, Beograd, Srbija \\ ${ }^{4}$ Institut za transfuziju krvi Srbije, Beograd, Srbija \\ ${ }^{5}$ Fakultet za fizičku hemiju, Univerzitet u Beogradu, Beograd, Srbija \\ ${ }^{6}$ Klinički centar Srbije, Beograd, Srbija \\ ${ }^{7}$ Specijalna bolnica za cerebrovaskularne bolesti "Sveti Sava”, Beograd, Srbija
}

\section{KRATAK SADRŽAJ}

Tema: Kidd krvnogrupni sistem je otkriven 1951. godine, a po Internacionalnom udruženju za transfuziju (ISBT) Kidd krvno grupni sistem je registrovan pod brojem 009. Antigeni Kidd sistema su detektovani na eritrocitima i u bubrezima. Incompatibilna transfuzija u Kidd sistemu dovodi do senzibilizacije i formiranja anti-Jka ili anti-Jkb antitela. Anti-Jka antitela retko mogu dovesti do akutne reakcije pa i oštećenja bubrega i hemoglobinurije. Najčešće anti-Jka antitela dovode do odložene hemolitičke transfuzijske reakcije. Cilj rada je da se naglase karekteristike anti-Jka antitela, njihova uloga u posttransfuzijskoj reakciji i mogućim kliničkim komplikacijama.

Pozicioniranje teme u medicinskoj stručnoj javnosti: Kidd antitela obično razaraju transfundovane inkompatibilne eritrocite u periodu od 7 i 21 dan. Odložena transfuziona hemolitička reakcija je posledica osobine anti.Jka antitela da brzo padnu do nemerljivih nivoa čak i nakon inkompatibilne transfuzije. U literature su opisani slučajevi odbacivanja transplantovanog bubrega u slučajevima pojave anti-Jka antitela. Takođe, postoje slučajevi kada se anti-Jka antitelo detektuje samo u prisustvu konzervansa kao šro su parabeni, Na-azid i druge supstance iz ove grupe; antibiotika koji su dodati u komercijalne reagense.Takođe, kod pacijenata na terapiji antibioticima ili monoklonskim antitelima, mogu se pri testiranju pojaviti lažno pozitivna anti-eritrocitna antitela.

Predlog budućih aktivnosti: Osim u životno ugražavajućim stanjima, potrebno je redukovati primenu alogene krvi. Klinički je opravdano povećati broj autolognih transfuzija u slučajevima kada stanje pacijenta to dozvoljava. Najbolji izbor bi bio primena univerzalnih eritrocita koji su lišeni eritrocitnih antigena. Kod svih pacijenata planiranih za terapiju monoklonskim antitelima ili za transplantaciju bubrega neophodno je uraditi proširenu fenotipizaciju eritrocita. Smatra se minimumom fenotipizacija na Rh, K, Jka, Jkb, Fya, Fyb i Ss antigene.

Ključne reči: transfuzija, Kidd sistem, Jka antitela, parabeni, transplantacija, antibiotici 